\title{
THE EFFECTIVENESS OF WEBTOON TO DEVELOP STUDENTS' WRITING SKILL IN NARRATIVE TEXT OF TENTH GRADER IN SMK PGRI 13 SURABAYA
}

\author{
Nova Ratnasari ${ }^{1}$, Linda Mayasari ${ }^{2}$, Sulton Dedi Wijaya ${ }^{3}$ \\ English Education Department, Faculty of Teacher Training Education \\ Muhammadiyah University of Surabaya \\ Email: novaratnasari06@gmail.com
}

\begin{abstract}
There are four main skills in learning English, writing, listening, reading, and speaking. In this research, the researcher focused on writing narrative text for tenth grader students of SMK PGRI 13 Surabaya. The medium that is used in this research is webtoon. It is kind of comic series which has picture and narration so it can be make the students learn how to write narrative text easier. The purpose of this research is to find out the effectiveness of webtoon in developing students' writing skill in narrative text. The researcher used quantitative method and the data were collected through pre-test, post-test, and questionnaire. The researcher used two classes, experimental class and control class to do this research. After the data were collected and calculated, the result showed that the average of score got an increasing. Before getting treatment, the average score of experimental class was 55 and after getting treatment, the average score was becoming 69. Furthermore, based on the students' response, it showed that mostly the students agreed that webtoon is useful to use in learning English, especially writing skill so webtoon can be effective to develop students' writing skill in narrative text.
\end{abstract}

Keywords: Writing, Narrative text, Webtoon.

English as a global language is very needed in this era. It has important role in the international interaction on many aspects and it means that English has become one of communication tools around the world. In Indonesia, English has been becoming one of the languages that should be learned. It is proved that all of educational levels in Indonesia always put English as a subject that have to be given to the students. One of the main skills of English is writing. Writing can be more important than others. According to Heaton (1975: 127) writing is a task which involves students to make grammatically correct sentences by manipulating words in the form of a piece of continuous writing with successfully communicates the writers' ideas on a certain topic. it means that the main purpose of writing is for expressing ideas, thoughts, and writing clearly, so the reader can get the point of what the writers do. Writing is important for non-verbal communication.

Writing also has a process, according to Hedge in McDonough and Shaw (2003:163), the writing process is divided into three stages: (a) Prewriting, author usually do prewriting or first draft to gain the idea of some subjects that they choose, it can be include some research and daydreaming, note-making and outlining, title-writing and lead-writing. In prewriting process, it usually takes 85 percents of the author's time; (b) Writing, writing is an act to produce a first draft. After doing prewriting, author gains some ideas and starts to write. Writing usually only takes one percent of writers time; (c) Rewriting, rewriting usually takes 14 percents of author's time because rewriting includes researching, rethinking, redesigning, rewriting, line-by-line editing until make each words properly placed.

According to Brown (2003:219), there are three kinds of writing. First is Academic writing such as essays, theses, papers, and others. Second is Job-related writing such as email, letters, and others. Last is Personal writing such as greeting cards, invitations, messages, and others. It means writing is very important to learn because it cannot be separated with human's daily life. In academic writing, usually there are several types of text 
that must be learned by the students, such as report text, procedure text, descriptive text, and narrative text.

Narrative text is an imagination story and usually has a purpose to entertain the reader. As an imagination story, narrative can be fiction or real story. Usually, the example of narrative text is legend or fairytale. According to Pardiyono (2007), There are text elements or generic structures in narrative text, those are: Orientation, topic includes activities or events that are 'incredible' that will be told. Sequence of events, or usually called complication which are problematic that leads to conflict climax. Resolution, contains explanation to problem solving that has been told until achieve the climax.

Teaching writing is not easy because it needs additional elements to make it completes. Those elements are grammatical, rhetorical, conceptual and judgmental (Heaton, 1975:135). Most teachers tend to teach writing only by giving explanation of text's structure, giving some examples, and then asking the students to make some text writing. But rather than using that old way, actually teachers are able to use different way to make students can be more interested to write, such as using webtoon as a medium.

Webtoon is a form of "website" and "cartoon". It firstly appeared in Korea before becoming so popular among the world. At first, many difference terms to call these digital comics which was published only on websites. One example is webmic (a compound of "web" and "comics"), which soon lost out to webtoon (a compound of "web" and "cartoon"). In 2000, one of Korean web portal had created a new site for internet comics named "Webtoon". Then webtoon became the standard term for comics that are created and consumed only thorugh the internet in South Korea. (Cho, 2016)

According to Wright (1989), media which have series picture like comic strips or webtoon can be used as a tool to create many interesting activities such as in teaching writing. Wright also stated that there are several roles of series pictures in teaching writing. First role is pictures can motivate the students and make them to pay more attention in the teacher. Another role is pictures can stimulate, and provide information to be referred in discussion to write narrative text. It means that it helps students to gain an information and idea so they can write a text without lacking of idea.

It has same condition in SMK PGRI 13 Surabaya, which the students do not have any interested in learning english, especially writing skill because english itself make them uninterested. So related to that reason, the researcher would like to conduct the experiment using webtoon for developing students' writing skill of tenth grader of Office Administration in SMK PGRI 13 Surabaya.

\section{RESEARCH METHODOLOGY}

In this research, the researcher used experimental design with the purpose to find out whether webtoon is effective to use and able to make students being more interest to learn writing in narrative text at SMK PGRI 13 Surabaya. In this case, the researcher divided two classes and compared them as the researcher explains it through this table below.

Table 1 The Design of Experimental Class and Control Class

\begin{tabular}{|l|l|l|l|l|l|l|}
\hline \multirow{2}{*}{ Class } & \multicolumn{2}{|l|}{ Pre-test } & \multicolumn{2}{l|}{ Treatment } & \multicolumn{2}{l|}{ Post-test } \\
\cline { 2 - 8 } & Yes & No & Yes & No & Yes & No \\
\hline Experimental Class & $\sqrt{ }$ & & $\sqrt{ }$ & & $\sqrt{ }$ & \\
\hline Control Class & $\sqrt{ }$ & & & $\sqrt{ }$ & $\sqrt{ }$ & \\
\hline
\end{tabular}


The participants of this research was the tenth grader of Office Administration (APK) in SMK PGRI 13 Surabaya which was X APK 2 (23 students) as an experimental class and X APK 3 (23 students) as a control class.

There are several instruments which were used in this research due to answer the hypothesis of the research. The research instruments are: (a) Pre-test, it was given to the both classes, experimental class and control class to measure the ability of the students before getting the treatment in experimental class. In this research, pre-test was given using same topic of writing narrative text to both classes; (b) Post-test, it was given to the both classes, experimental class and control class after experimental class getting the treatment. Post-test was used to measure the development of the students' ability in writing narrative text; (c) Lesson Plan, it was used by english teacher to teach the students in experimental class. The english teacher should teach the students using the lesson plan appropriately. Before the Lesson Plan was used, it had been validated by two validators. The first validator was the lecture of writing class and the second validator was english teacher of SMK PGRI 13 Surabaya. The lesson plan was also used as the treatment in teaching writing narrative text in experimental class. It means the lesson plan as a treatment tool was used after experimental class getting the pre-test; (d) Questionnaire, after completing the three first instruments, the researcher gave questionnaire to all students who had participated to the research. In the questionnaire, there are some questions related to the use of webtoon as medium for teaching writing narrative text. The students answered the questions based on their own responses about the medium that is used.

After collecting the data, the researcher analyzed it. In this study, the researcher used several calculation tests to analyze the results. The tests are validity test, reliability test, normality test, homogeneity test, and T-test which are to find out whether there is significant difference in experimental class and control class or not.

The researcher calculated the tests by using SPSS 20 and the steps of data analysis technique in this research include: (a) Validity Test, it is used to assess whether the lesson plan is ready to use or not; (b) Reliability Test, it is to know whether the test scoring from rater 1 and rater 2 is reliable or not; (c) Normality Test, it is to know whether the distribution of the data is normal or not; (d) Homogeneity Test, it is to know if the students' ability in writing of both classes, experimental class and control class are homogeneous or not; $(e) T$ Test, there are two types of T-Test that are used in this research, T-Test using Independent Sample T-Test and Paired Sample T-test of both classes. The purpose of Independent Sample T-Test is to see whether webtoon is effective to use in teaching writing narrative text or not. Whereas Paired Sample T-Test is used to find out the significant difference before and after doing the treatment; (f) Questionnaire, it is used to know the interest of the students after doing the treatment using webtoon.

\section{FINDING AND DISCUSSION Finding}

In this research, during the experiment, the researcher was giving the pre-test and post-test for both experimental class and control class but for experimental class, the researcher was also doing the treatment before giving the post-test. After the both class doing the pre-test and post-test, the researcher did the scoring using writing scoring rubric by Brown and Bailey. These are the data analysis of the students scores and interest.

\section{The result of data analysis}

Before conducting the research, the tests that are used in pre-test and post-test, and also the lesson plan should be validated by the experts to see whether the tests and lesson plan could be used or not. Validity has a purpose to assess whether the lesson plan is valid to use or not. In this case, the researcher asked a help from the lecture who is experts in this 
field to assess the lesson plan, she is Sofi Yunianti, S.S, M.Pd, one of lectures in Muhammadiyah University of Surabaya. Another help was asked by the researcher to english teacher in SMK PGRI 13 Surabaya itself, she is Ani Dwi Widiastuti, S.Pd. The result was the lesson plan and tests are valid to use to conduct the research. After the instruments was validated, the researcher could apply it in this experiement.

In scoring the tests, the researcher used inter-rater reliability which means that the scoring of tests for both classes were done by two raters. The first rater was the english teacher of tenth grader in SMK PGRI 13 Surabaya and the second rater was the researcher. Then the result of pre-test and post-test scores were analyzed by using SPSS 20 to know if the scoring two raters are reliable or not. In this case, the researcher used Pearson Correlation to analyze the reliability of two raters.

Table 2 Reliability Test of Rater Using Pre-test Score

Correlations

\begin{tabular}{|cc|c|c|}
\hline & & rater_1 & rater_2 \\
\hline \multirow{2}{*}{ rater_1 } & Pearson Correlation & 1 &, $916^{* *}$ \\
& Sig. (2-tailed) & &, 000 \\
& N & 23 & 23 \\
& Pearson Correlation &, $916^{* *}$ & 1 \\
rater_2 & Sig. (2-tailed) &, 000 & \\
& $\mathrm{~N}$ & 23 & 23 \\
\hline
\end{tabular}

**. Correlation is significant at the 0.01 level (2-tailed).

The result of reliability test of pre-test score that had been calculated using Pearson Correlation of two raters is $0.916^{* *}$ and it means that the data of pre-test score are reliable. It also means that the level of correlation is very strong because based on the scale of reliability, the interval coefficient $0,80-1,000$ is considered has very strong level of correlation.

Table 3 Reliability Test of Rater Using Post-test Scrore Correlations

\begin{tabular}{|cc|c|c|}
\hline & & rater_1 & rater_2 \\
\hline \multirow{2}{*}{ rater_1 } & Pearson Correlation & 1 &, $828^{* *}$ \\
& Sig. (2-tailed) & &, 000 \\
& $\mathrm{~N}$ & 23 & 23 \\
& Pearson Correlation &, $828^{* *}$ & 1 \\
rater_2 & Sig. (2-tailed) &, 000 & \\
& $\mathrm{~N}$ & 23 & 23 \\
\hline
\end{tabular}

**. Correlation is significant at the 0.01 level (2-tailed).

The result of reliability test of post-test score that had been calculated using Pearson Correlation of two raters is $0.828^{* *}$ and it means that the data of post-test score are reliable, because based on the scale of reliability, the interval coefficient $0,80-1,000$ is considered has very strong level of correlation.

After doing the reliability test and the results are all the data have very strong level of correlation, the researcher calculated the minimum, maximum, and the mean or average score of pre-test and post-test in both classes. It was to find out the comparison between the scores of two classes so the researcher was able to know the efferctiveness of webtoon to develop students' writing skill in narrative text. 
Table 4 Pre-test's Score

Descriptive Statistics

\begin{tabular}{|c|c|c|c|c|c|}
\hline & N & Minimum & Maximum & Mean & Std. Deviation \\
\hline experimental_class & 23 & 38 & 69 & 55,61 & 10,522 \\
control_class & 23 & 41 & 69 & 55,52 & 7,663 \\
Valid N (listwise) & 23 & & & & \\
\hline
\end{tabular}

The classes are contain with 23 students and the passing grade in SMK PGRI 13 Surabaya for any lessons is 70. The table shows that in pre-test, the minimum score of experimental class is 38 and the maximum score is 69. Meanwhile in control class, the minimum score is 41 and the maximum score is also 69. Although the score are different between both classes, the mean score are equal, which is 55 .

Table 5 Post-test's Score

Descriptive Statistics

\begin{tabular}{|c|c|c|c|c|c|}
\hline & $\mathrm{N}$ & Minimum & Maximum & Mean & Std. Deviation \\
\hline experimental_class & 23 & 53 & 81 & 69,48 & 7,657 \\
control_class & 23 & 45 & 76 & 62,30 & 9,541 \\
Valid N (listwise) & 23 & & & & \\
\hline
\end{tabular}

In post-test, the minimum score of experimental class is 53 and the maximum score is 81 . Meanwhile in control class, the minimum score is 45 and the maximum score is 76 . The mean score of post-test in both classes are different, experimental class is 69 and control class is 62 . Even though both classes have higher mean score than in pre-test, experimental class itself is higher than control class. It means the writing skill of the students in experimental class has developed.

After finding the mean score to see the development of students' skill in writing narrative text, the researcher calculated the normality and the homogeneity test to see whether the data have normal distribution and homogneous or not.

Table 6 Normality Test of Post-test in Experimental Class and Control Class One-Sample Kolmogorov-Smirnov Test

\begin{tabular}{|ll|c|c|}
\hline & & experimental_class & control_class \\
\hline N & & 23 & 23 \\
Normal Parameters & & \\
& Mean & 69,48 & 62,30 \\
& Std. Deviation & 7,657 & 9,541 \\
Most Extreme Differents & Absolute &, 144 &, 107 \\
& Positive &, 066 &, 107 \\
Kolmogorov-Smirnov Z & Negative &,- 144 &,- 106 \\
Asymp. Sig. (2-tailed) & &, 691 &, 513 \\
\end{tabular}

a. Test distribution is Normal.

b. Calculated from data.

Criteria of Hypothesis:

Significance value $(\mathrm{p})>\alpha(0.05)=$ the test distribution is normal

Significance value $(\mathrm{p})<\alpha(0.05)=$ the test distribution is abnormal

As it can be seen in the table above that the significance value of experimental class is 0.727 and the significance value of control class is 0.955 . The significance values of both classes are higher than $\alpha=0.05$ (experimental class $=0.727>0.05$ and control class $=0.955$ $>0.05$ ). It means that both classes have same result of normality test which is $p>\alpha$ so, it can be concluded that the test distribution of pre-test in both classes is normal. 
Table 7 Homogeneity Test

Test of Homogeneity of Variances

Score

\begin{tabular}{|l|l|l|l|}
\hline Levene Statistic & \multicolumn{1}{|c|}{ df1 } & \multicolumn{1}{|c|}{ df2 } & Sig. \\
\hline 1,262 & 1 & 44 &, 267 \\
\hline
\end{tabular}

The criteria of hyphothesis of homogeneity test can be seen as follow:

$\mathrm{H}_{0}$ is accepted and $\mathrm{H}_{1}$ is not accepted if significance value $(\mathrm{p})>\alpha(0.05)$. It means that the students' ability of experimental class and control class is homogeneous.

$\mathrm{H}_{1}$ is accepted and $\mathrm{H}_{0}$ is not accepted if the significance value $(\mathrm{p})<\alpha(0.05)$. It means that students' ability of experimental class and control class is not homogeneous.

Based on table above, it can be seen that significance value (p) is higher than $\alpha$ (0.05) which is $0.267>0.05$. It means that $\mathrm{H}_{0}$ is accepted and $\mathrm{H}_{1}$ is refused, so the result is the students' ability of both experimental class and control class are homogeneous.

After doing calculation of normality test and homogeneity test, the researcher calculated the T-Test using Independent Sample T-Test and Paired Sample T-test of both classes. The purpose is to see whether webtoon is effective to use in teaching writing narrative text or not. To calculate T-test, the researcher use the criteria of hyphothesis that can be seen as follow:

$\mathrm{H}_{0}=$ Sig. (2-tailed) $>\alpha(0.05)$. It means that there is no significant difference in students' ability of writing narrative text in both classes.

$\mathrm{H}_{1}=$ Sig. (2-tailed) $<\alpha(0.05)$. It means that there is significant difference in students' ability of writing narrative text in both classes.

Table 8 Independent Sample T-Test of Pre-test

Independent Samples Test

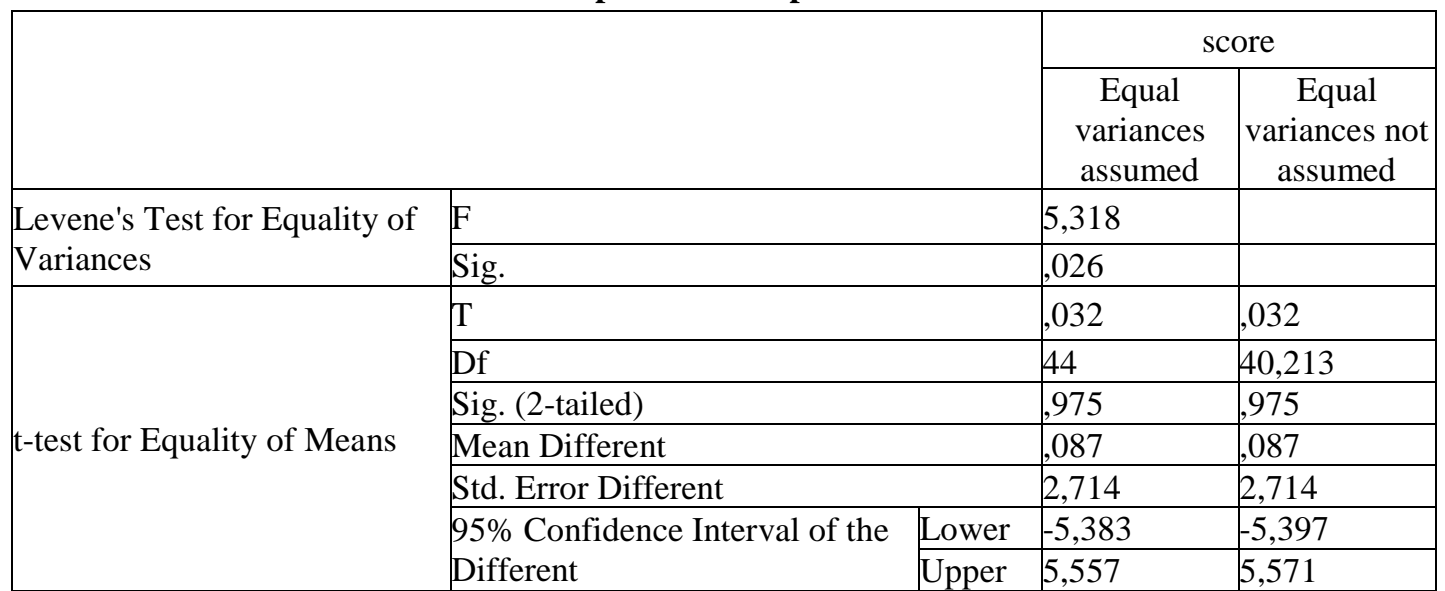

The table above shows that the significance value (2-tailed) or Sig. (2-tailed) is 0.975 . It shows that the value of Sig. (2-tailed) is higher than $\alpha(0.05)$ and it can be written as $0.975>0.05$. Because of Sig. (2-tailed) is higher that 0.05 , the result is $\mathrm{H}_{0}$ is accepted and it means that there is no significant difference between experimental class and control class in ability to write narrative text before the treatment was conducted. 
Table 9 Independent Sample T-Test of Post-test

Independent Samples Test

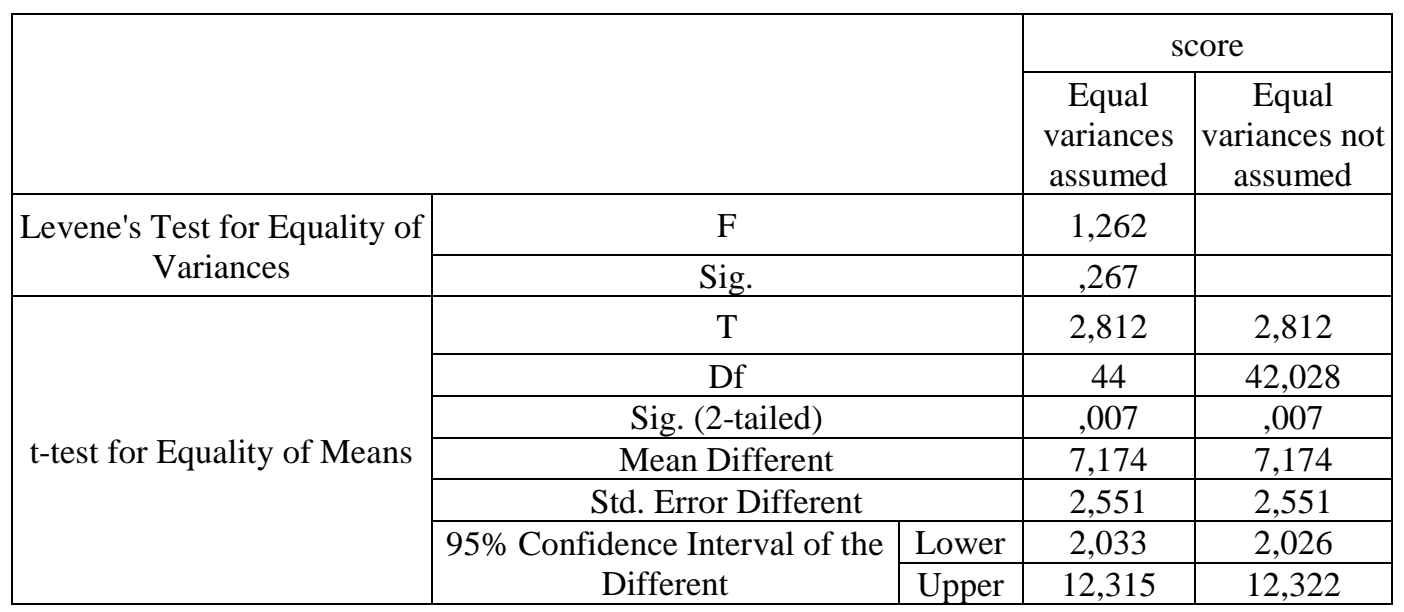

In the table of Independent Sample T-Test of post-test, shows that the value of Sig. (2-tailed) is 0.007. In this case, the value of Sig. (2-tailed) is lower than $\alpha(0.05)$ and it can be written as $0.007<0.05$. Because of Sig. (2-tailed) is lower than 0.05 , the result is $\mathrm{H}_{1}$ is accepted and it means that there is significant difference between experimental class and control class in ability to write narrative text after the treatment was conducted in experimental class by using webtoon as a medium.

After calculating Independet T-Test, the researcher calculated Paired Sample T-Test. It is used to see the development progress of the students in experimental class in writing narrative text using webtoon as a medium. The data that should be used to calculate Paired Sample T-Test are the score of pre-test and post-test in experimental class.

Table 10 Paired Sample T-Test of pre-test and post-test in Experimental Class Paired Samples Test

\begin{tabular}{|lll|l|}
\hline & & & Pair 1 \\
\cline { 2 - 3 } & & Mean & post-test - pre-test \\
\hline & Std. Deviation & & 13,86957 \\
Paired Differents & Std. Error Mean & & 9,57888 \\
& 95\% Confidence Interval of the Different & Lower & 9,72735 \\
& & Upper & 18,01178 \\
T & & & 6,944 \\
Df & & & 22 \\
Sig. (2-tailed) & & & \\
\hline
\end{tabular}

From the table above, it can be seen that Sig. (2-tailed) is 0.000 and clearly the value is lower than $\alpha(0.05)$ and it can be written as $0.000<0.05$. In this case, because of Sig. (2tailed) is lower that 0.05 , the result is $\mathrm{H}_{0}$ is rejected and $\mathrm{H}_{1}$ is accepted. It means that there is significant difference in progress of experimental class before and after doing the treatment.

The last data analysis is Eta Squared. It is used to measure the effect size for paired sample t-test. It can be the real prove whether the medium is effective or not. The formula and calculation of eta squared can be seen below.

$$
\begin{gathered}
\text { Eta Squared }=\frac{t^{2}}{t^{2}+(N-1)} \\
\text { Eta Squared }=\frac{(6.944)^{2}}{(6.944)^{2}+(23-1)}
\end{gathered}
$$




$$
\begin{aligned}
\text { Eta } \text { Squared } & =\frac{48.219136}{48.219136+22} \\
\text { Eta Squared } & =\frac{48.219136}{70.219136}=0.68
\end{aligned}
$$

From the calculation of eta squared above, the result is 0.68 and according to the guidelines that proposed by Cohen, the interpretation of this eta squared is it has 'large effect' because it is higher than 0.14 which supposed to be the minimum value of 'large effect'. It means, webtoon has large effect or it can be called as effective to use as a medium in teaching writing narrative text for tenth grader in SMK PGRI 13 Surabaya.

\section{The result of Questionnaire}

Questionnaire was prepared by the researcher to see the students' responses of interest in experimental class after getting the treatment by using webtoon in learning writing narrative text. The students' responses were very useful to find out whether webtoon is effective to develop their writing skill in narrative text or not, and also to know whether webtoon make the students more interested in writing text or not. Here the result of questionnaire calculation.

\begin{tabular}{|c|c|c|c|c|c|c|c|c|c|}
\hline \multirow{3}{*}{$\mathbf{Q}$} & \multicolumn{4}{|c|}{ Answer } & \multirow{3}{*}{$\mathbf{Q}$} & \multicolumn{4}{|c|}{ Answer } \\
\hline & \multicolumn{2}{|c|}{ Yes } & \multicolumn{2}{|c|}{ No } & & \multicolumn{2}{|c|}{ Yes } & \multicolumn{2}{|c|}{ No } \\
\hline & $\mathbf{N}$ & $\%$ & $\mathbf{N}$ & $\%$ & & $\mathbf{N}$ & $\%$ & $\mathbf{N}$ & $\%$ \\
\hline 1. & 23 & $100 \%$ & 0 & $0 \%$ & 6. & 4 & $17 \%$ & 19 & $83 \%$ \\
\hline 2. & 23 & $100 \%$ & 0 & $0 \%$ & 7. & 18 & $78 \%$ & 5 & $22 \%$ \\
\hline 3. & 23 & $100 \%$ & 0 & $0 \%$ & 8. & 22 & $96 \%$ & 1 & $4 \%$ \\
\hline 4. & 23 & $100 \%$ & 0 & $0 \%$ & 9. & 23 & $100 \%$ & 0 & $0 \%$ \\
\hline 5. & 20 & $87 \%$ & 3 & $13 \%$ & 10. & 22 & $96 \%$ & 1 & $4 \%$ \\
\hline
\end{tabular}

Table 11 Table of Questionnaire Calculation

From the students' responses that had been calculated by the researcher, the result is 5 questions have $100 \%$ agreement from the students. The 5 questions are including; the students agreed if webtoon is used to learn narrative text in their school; the students prefer to learn writing narrative text using webtoon rather than school book because it is easier; webtoon is able to make the students more interested to learn writing narrative text; the students also think that webtoon is very useful, especially in learning narrative text; and webtoon is able to increase their motivation in learning english. It means that the students got more interest in webtoon rather than other medium to learn narrtive text, so it can be concluded that the students are able to use webtoon easily as a learning medium.

\section{Discussion}

Based on the result and data analysis, it can be concluded that the use of webtoon to develop the students' writing ability especially writing narrative text in SMK PGRI 13 Surabaya give a significant effect. The significant effect means that the use of webtoon in this research is considered to be effective. The statement that webtoon as a medium is considered to be effective can be proved by two criteria, according to Dunne (1996:12), first, webtoon can make the students get a skill that is approved by the teachers, in this case, it can be analyzed from the increasing of average score of experimental class, the development of the students' skill in each aspects, and the result of T-Test calculation; second, webtoon can make the students learning writing easily, in this case, the researcher analyzed from the 
students' responses through questionnaire to know the students' feeling and interest to the use of webtoon.

Finally, from finding of the result that had been discussed, it can be concluded that webtoon is effective to improve the students' writing skill in narrative text, because Wright (1989) stated that actually comic strips or webtoon are a sequence of pictures which is related to a narrative text so it helps the students to develop their writing skill. Wright (1989) also stated that media which have series picture like comic strips or webtoon can be used as a tool to create many interesting activities such as in teaching writing. It could be the reason how the students found it interesting and it was able to increase their motivation in learning english especially in writing narrative text.

\section{CONCLUSION}

The researcher had done this research in SMK PGRI 13 Surabaya, Jalan Sidosermo III, Sidosermo, Wonocolo, Surabaya. This research was held from April $12^{\text {th }} 2018$ until May $11^{\text {th }} 2018$. The researcher used X APK 2 as an experimental class and X APK 3 as a control class and the result is webtoon is effective to develop students writing skill in narrative text of tenth grader in SMK PGRI 13 Surabaya. Based on the result of this research, some suggestions are given to the English teachers, the students, and the future researcher. The English teachers are suggested to apply webtoon as a medium in teaching writing so the students can enjoy their learning process. The students are suggested to be more enthusiasted, motivated, and interested in learning English, especially in writing skill and they can also learn any skills through webtoon, considering webtoon helps them increase their score. The future researchers are suggested to use webtoon as a medium to develop students' other skills, such as reading, because it has narration and many interesting stories.

\section{REFERENCES}

Brown, H. D. (2003). Language Assessment Principles and Classroom Practices. California: Longman University Press.

Cho, H. (2016). The Webtoon: A New Form for Graphic Narrative. Dipetik May 5, 2018, dari The Comics Journal: www.tcj.com/the-webtoon-a-new-form-for-graphicnarrative/

Heaton, J. B. (1975). Writing English Language Test. England: Longman.

McDonough J., C. S. (2003). Materials and Methods in ELT. Malden: Blackwell.

Pardiyono. (2007). Bahasa Indonesia. Bandung: CV. Andi Offset. Company Inc.

Wright, A. (1989). Pictures for Language Learning. Cambridge: Cambridge University Press. 